\begin{tabular}{|l|l|l||}
\hline \multicolumn{2}{|c|}{ PublisherInfo } \\
\hline \hline PublisherName & $:$ & BioMed Central \\
\hline \hline PublisherLocation & $:$ & London \\
\hline \hline PublisherImprintName & $:$ & BioMed Central \\
\hline \hline
\end{tabular}

\title{
Big DNA, small channels
}

\begin{tabular}{|l|l|l||}
\hline \multicolumn{2}{|c|}{ ArticleInfo } \\
\hline \hline ArticleID & $:$ & 3684 \\
\hline \hline ArticleDOI & $:$ & $10.1186 /$ gb-spotlight-20000516-02 \\
\hline \hline ArticleCitationID & $:$ & spotlight-20000516-02 \\
\hline \hline ArticleSequenceNumber & $:$ & 121 \\
\hline \hline ArticleCategory & $:$ & Research news \\
\hline \hline ArticleFirstPage & $:$ & 1 \\
\hline \hline ArticleLastPage & $:$ & 2 \\
\hline \hline & & RegistrationDate : 2000-05-16 \\
ArticleHistory & $:$ & OnlineDate \\
\hline \hline ArticleCopyright & $:$ & BioMed Central Ltd2000-05-16 \\
\hline \hline ArticleGrants & $:$ & \\
\hline \hline ArticleContext & $:$ & 130591111 \\
\hline \hline
\end{tabular}




\section{William Wells}

Email: wells@biotext.com

The key to pulsed-field gel electrophoresis (PFGE) is the relaxation of hefty DNA molecules when the current is reduced. Han and Craighead report achieving the same thing in the 12 May Science by using thick regions of microfabricated channels as relaxation chambers, with alternating thin regions performing the separation function (Science 2000, 288:1026-1029). A thirty minute run through a channel (which has $75 \mathrm{~nm}$ diameter and $1.8 \mathrm{~mm}$ diameter regions repeated every $4 \mathrm{~mm}$ over a total length of $15 \mathrm{~mm}$ ) suffices to separate a mixture of DNA with resolution comparable to an 11 hour PFGE run. Reducing the current allows sample concentration before a run, and the lack of gel matrix should facilitate the integration of this apparatus with other microfabricated devices.

\section{References}

1. Science magazine, [http://www.sciencemag.org/] 